\title{
The Role of Islamic Crowdfunding Mechanisms in Business and Business Development
}

\author{
Achsania Hendratmi, ${ }^{1}$ Puji Sucia Sukmaningrum, ${ }^{2}$ Muhamad Nafik Hadi Ryandono, ${ }^{3}$ Ririn \\ Tri Ratnasari ${ }^{4}$
}

Faculty of Economics and Business, Universitas Airlangga, Jl. Airlangga No.4, 60286, Surabaya, Indonesia

\begin{abstract}
Objective - This study aims to determine the role of Islamic crowdfunding towards business development of start-up businesses financed in Singapore, Malaysia and Indonesia.

Methodology/Technique - This study uses a qualitative approach with an exploratory case study strategy. The data collection was carried out by conducting in-depth interviews with CEOs and COOs of Kapital Boost and CEO Investee (funded SMEs) informants.

Findings - The results show that there is an increase in assets, sales turnover, and the capacity of Micro, Small and Medium Enterprises (MSMEs) and Startup businesses that received funding through campaigns on the Kapital Boost platform. In addition, pioneering business people can get easier access to financing compared to financing through bank-provided credit.
\end{abstract}

Novelty - The findings of this paper can be used to develop crowdfunding platform will be implemented in Muslim countries or countries with a majority Muslim population.

Type of Paper: Empirical.

JEL Classification: E44, M21, M29.

Keywords: Crowdfunding Platforms; Islamic Crowdfunding; Business Development; MSMEs; Start-up Companies.

\section{Introduction}

Nowadays, business start-ups and SMEs still encounter a number of problems in their development. One of the biggest problems is the limited support of the banking industry to micro, small and start-up businesses due to the risk involved with investing in new businesses (obtaining financial assistance at the initial stage of a SMEs venture is a common problem faced by many entrepreneurs) (Douglas \& Hughers, 2009). In most cases, entrepreneurs use bootstrapping techniques to raise capital and mitigate financial loss by boosting short-term profits (Winborg \& Landstrom, 2001). This problem becomes worse when they are not able to provide collateral for financial assistance and face difficulty attracting investors due to insufficient cash of the business start-up as well as the presence of significant information asymmetry with investors.

\footnotetext{
* Paper Info: Revised: December 14, 2018

Accepted: March 19, 2019

* Corresponding author: Achsania Hendratmi

E-mail: achsania.hendratmi@feb.unair.ac.id

Affiliation: Faculty of Economics and Business, Universitas Airlangga, Indonesia.
} 
Crowdfunding is an innovation for micro business financing and start-up facilities which uses technology that facilitates investors. This form of disintermediated finance seems particularly suitable for funding early stage entrepreneurial firms (Cumming \& Vismara, 2017), which tend to be insufficiently developed to attract intermediated finance such as venture capital or bank lending (Brown et. al., 2017). Indeed, some claim that the use of crowdfunding may be a new form of entrepreneurial bootstrapping used by innovative resourceconstrained start-ups (Bellavitis, Filatotchev, Kamuriwo, \& Vanacker, 2017).

During the development of Islamic finance, the Islamic finance industry also penetrated this investment mechanism, namely, in the form of an Islamic crowdfunding platform for financing investment. The Islamic crowdfunding platform is a sharia-based crowdfunding system that funds halal projects and products that are permitted in Islamic law. The products and the funds invested must be lawful (Marzban \& Asutay, 2014) It is estimated that the total amount of Sharia Compliant Crowdfunding in 2015 totaled \$30 million. One factor which may also boost the growth of the sector is the increased introduction of Islamic finance structures to meet the specific needs of SMEs and limit the risk to investors. Most crowdfunding platforms currently use Murabaha (cost plus profit margin) and Mudharabah (profit sharing) contracts. Other structures which may be considered include Salam (forward financing transaction), Ijara (leasing), and Diminishing Musharaka (diminishing equity partnership) (Ahammed, 2017).

The IFSB identifies five active Sharia Compliant Crowdfunding platforms with a primary location in a country of the Organisation of Islamic Cooperation (OIC). The Crowdsurfer database identifies 14 equitybased and 13 commercial loan-based crowdfunding platforms with an "active" status. From the profiles of the platforms in the Crowd surfer database, one can identify only 4 active "Islamic" crowdfunding platforms with a primary location in an OIC member state.

Kapital Boost, which is headquartered in Singapore and aims to provide assistance by way of finance to start-ups and SMEs in Southeast Asia according to sharia principles. Kapital Boost has a variety of SMEs and startup business platforms that are managed, the basic website mechanism is a means to communicate various potential startup profiles to attract potential investors and select potential for business sustainability and business development (World Back Group Islamic Development Bank-G20 Policy Paper).

Business development is one indicator of the attractiveness and trust of investors. The concept of business development is the ability to create long-term value of a business including the value of customers, markets, and networks. Business development is characterized by increased profitability, growth in product development and expansion. Activities in business development cover all functional areas including sales, marketing, product or project management and the ability to build networks and partnerships.

This study aims to determine the role of Islamic Crowdfunding in the development of MSMEs and start-up businesses that are financed through the Kapital Boost platform. This research is expected to be able to provide a pilot business development model through an Islamic crowdfunding mechanism to increase the contribution of new businesses to the economy.

\section{Literature Review}

\subsection{The Concept of Entrepreneurship}

Marzban et. al. (2014) suggest that the term "entrepreneurship" is directly related to innovation, technology and growth while in some developing countries, more micro-medium businesses are struggling to penetrate the market and survive. According to the Global Entrepreneurship Monitor (2013), the term "entrepreneurship" is generally categorized as "entrepreneurship by necessity" or "entrepreneurship by opportunity". Entrepreneurship by necessity is entrepreneurship which is driven by the need to generate income to survive because it does not get job opportunities whereas entrepreneurship by opportunity is defined by the Commission of the European Communities (2003) as a "mindset and process to create and develop economic activity by blending risk-taking, creativity and/or innovation with sound management 
within a new or implementing organization". Entrepreneurship is the process of creating and building economic activity by combining one's courage to take risks, creative abilities and innovation in providing solutions to problems.

\subsection{Crowdfunding}

Crowdfunding is a financing innovation that uses technology to facilitate donors and as one of the traditional financing solutions such as banking and cooperatives in general (Mollick, 2014). The crowdfunding mechanism is an alternative to bank finance which can be very difficult for new businesses. In the last few years, crowdfunding mechanisms have continued to grow and provide funding for new business opportunities (Najah \& Jarboui, 2015)

There are four models of crowdfunding (Rees-Mogg, 2013; Marzban et. al., 2014). The first is DonationBased Crowdfunding, whereby investors provide funding without any expectations of return; the investors typically receive certain rewards such as inclusion on an album cover, event tickets etc. that are not tangible. Crowdfunding is usually driven by personal motivation to help (charity). The second is Reward-based Crowdfunding in which donors receive rewards for supporting a project in the form of prizes or awards.

The third type is Loan-Based (peer-to-peer) Crowdfunding, that is, investors receive their money back by way of profit sharing. In Loan-based crowdfunding, investors receive a return with an interest payment or return plus interest. Crowdfunding is often an alternative source of conventional funding by banks or other conventional finance institutions. The fourth type is Equity-Based Crowdfunding which is a form of investment whereby a collection of investors provide capital support to a business with a view to obtain a return on their investment (financial gain).

\subsection{Crowdfunding Platforms (CPs)}

Crowdfunding platforms are online intermediaries that facilitate the process of transfer of funds from those who are looking to donate or invest to those in need of capital. The platforms operate by allowing those seeking finance to make a pitch on the site outlining how much money they need, what they need it for and what, if anything, investors receive in return for contributing. Potential funders can then view those pitches on the platform, interact with those looking for finance and other potential funders and decide whether or not to invest. The majority of platforms operate an all-or-nothing model where, if the target amount is not raised within a given timeframe, contributions are returned to funders and no financing goes ahead (Ahamed, 2017).

\subsection{Islamic Crowdfunding}

The concept of Islamic crowdfunding is almost the same as the concept of crowdfunding in general. The difference lies in the application of an "asset-backed" transaction mechanism and profit loss margin (Asutay \& Marzban, 2012). Marzbah and Asutay (2014) propose a crowdfunding model that is in accordance with Islamic principles, shown in Table 2.1 below.

Table 2.1. Crowdfunding Instruments and Models from an Islamic Perspective

\begin{tabular}{|c|c|c|c|}
\hline $\begin{array}{c}\text { Financing } \\
\text { Objectives }\end{array}$ & Crowdfunding Model & Form of potential entities & $\begin{array}{c}\text { Contract } \\
\text { Instruments }\end{array}$ \\
\hline Islamic Charity & Donation Based & Microfinance Institutions & Hibah \\
& & & Mard Hasan \\
& & & Murabaha \\
\hline
\end{tabular}




\begin{tabular}{|c|c|c|c|}
\hline Product & Reward based & $\begin{array}{c}\text { Microfinance Institutions } \\
\text { Micro \& Small Business } \\
\text { Startup Business }\end{array}$ & Buy and Sell /Ba'i \\
\hline \multirow[t]{4}{*}{ Investment } & \multirow[b]{2}{*}{ Loan Based/Debt Based } & Microfinance Institutions & \multirow[b]{2}{*}{$\begin{array}{c}\text { Murabaha } \\
\text { Ijarah }\end{array}$} \\
\hline & & Micro \& Small Business & \\
\hline & \multirow[t]{2}{*}{ Equity Based } & $\begin{array}{l}\text { Small \& Micro Business } \\
\text { (Small Enterprises) }\end{array}$ & $\begin{array}{c}\text { Syirkah al aqd \& al } \\
\text { milk }\end{array}$ \\
\hline & & Startup Business & Musharakah \\
\hline
\end{tabular}

\subsection{Micro, Small, Medium Enterprises (MSME)}

MSMEs are, collectively, the largest employers in many low-income countries, yet their viability is threatened by a lack of access to risk-management tools such as savings, insurance and credit. Their growth is often stifled by restricted access to credit, equity and payments services (World Bank, 2013).

Access to financial services can therefore boost job creation, raise income, reduce vulnerability and increase investment in human capital. MSMEs account for a significant share of employment and GDP around the world, however, with limited access to finance, the economy suffers a series of negative consequences including the restriction of economic and social opportunities, the reduction of enterprise creation and growth, increased vulnerability of households and enterprises to threats, and more expensive and risky payments.

A World Bank Enterprise Survey (2013) found that the smaller firms are less likely to have access to capital - a factor that restricts their ability to grow and become more productive. They are also more likely to rely on informal sources of capital - a factor that is often negatively associated with growth and firm performance. Access to finance is disproportionately difficult for smaller firms in the least developed countries (LDCs), with $41 \%$ of SMEs in LDCs reporting access to finance as a major constraint to their growth and development, by comparison to $30 \%$ in middle-income countries (MICs) and only $15 \%$ in highincome countries (HICs).

\subsection{Business Development}

Sustainability in business consist of business strategy that drives long term growth and profitability, mandating the inclusion of environmental and social issues. Business development is one indicator of the attractiveness and trust of investors. John Pollack from Forbes (2015) says that business development is an activity and process of analysis regarding potential growth opportunities along with support and growth monitoring. The concept of business development is the ability to create long-term value of a business including the value of customers, markets and networks. Business development is characterized by increased profitability; businesses start to grow both in product development and expansion. Activities in business development cover all functional areas namely: sales, marketing, product or project management and the ability to build networks and partnerships. 


\section{Research Method}

\subsection{Research Approach}

This study uses a qualitative approach with a case study research strategy. The case study is an empirical inquiry that investigates phenomena in a real-life context, when the boundaries between the phenomena and context do not appear firmly and where multiple sources of evidence are used (Yin, 2014:3). The case study used is an explanatory case study. An explanatory case study involves comparing each theory of crowdfunding with the actual practice of Kapital Boost crowdfunding companies.

\subsection{Analysis Unit}

The unit of analysis in this study is the Kapital Boost mechanism which manages Islamic crowdfunding so that the managed pilot business platform can generate promising returns to investors. Then, every startup business that is on the website-based crowdfunding platform which includes financial performance and business development.

\subsection{Source and Type of Data}

Afifuddin and Saebani (2009:119) explain that in qualitative research, data collection is conducted not only through participation, but also through literature, both as primary data and secondary data. The sources of data in this study are divided into two categories, namely: primary data and secondary data. Primary sources are sources of data obtained directly from sources, either from individuals or individuals and documents. Secondary sources are sources that do not directly provide data to data collectors, for example, archives, reports and relevant documents obtained through other people or through documents and literature reviews (Sugiyono, 2012:137)

The primary data used as the data source in this study includes: in-depth interview interviews with Kapital Boost CEO, Erly Witoyo as Key Informant at Kapital Boost office (Changi Rd \# 04-07 Singapore). Key Informants (KI) are expected to give information about the general description of Kapital Boost, the mechanism of crowdfunding financing systems, and the role of crowdfunding in the development of investee businesses (SMEs funded). An in-depth Interview was conducted with the Chief Financial Officer as informant 1 (IN1). Snowball techniques were used to select the informants, meaning that it did not rule out the possibility of informants being recommended by Key Informants and Key Informants in the field of crowdfunding, particularly the CEOs of the Investee (SMEs funded). The sources of the business start-up informants are shown in Table 2.2 below.

Table 2.2. Sources of Business Start-Up Informants

\begin{tabular}{|l|l|}
\hline Start-Up & Country \\
\hline Telaga Pelangi & Indonesia \\
\hline Wahana Cipta Adhikarya & Indonesia \\
\hline IG Tech \& Resources & Malaysia \\
\hline Santai Reflexiologi & Malaysia \\
\hline Southern Food Industries & Singapore \\
\hline Fleur & Singapore \\
\hline
\end{tabular}

The secondary data used includes investee financial report data, Kapital Boost development reports and all data regarding the Investee funded by Kapital Boost. 


\subsection{Data Collection Process}

Data collection techniques are the most strategic steps in research, because the main purpose of research is to obtain data (Sugiyono, 2012). The data collection techniques in the study were carried out through the following processes (Yin, 2009).

\subsubsection{Observation}

Observation is the process of recording the behavior patterns of subjects (people), objects or systematic events without any questions or communication with the individuals studied. Evidence of observation is often useful to provide additional information about the topic.

\subsubsection{Interview}

An interview is a method of collecting data by asking someone who is an informant or respondent questions about the study topic. Interviews are essential for case studies, because case studies are generally concerned with humanitarian affairs.

\subsubsection{Documentation}

The types of documents used are in the form of letters, memoranda, official announcements, agendas, conclusions of meetings, reports of written events, administrative documents (proposals, progress reports, and other internal documents), studies or official evaluations on the same site, new clippings and other articles that appear in the mass media.

\subsection{Data Analysis Technique}

This study uses data analysis techniques in the form of data processing of the findings of the interviews and documentation. There are two techniques used to analyze the data, namely: domain taxonomy, and compound analysis Domain Analysis and Taxonomy Analysis.

Domain Analysis is used to obtain an overall picture of the object of the research. Various domains or categories were found from the monitor questions. The researchers assigned certain domains as a basis for further research.

Taxonomy Analysis is used when the selected domain is translated into more detail, to determine how to conceptualize its business model. This analysis is performed by observation focused on the chosen domain.

\section{Results and Discussion}

\subsection{Kapital Boost as an Islamic Crowdfunding Intermediary}

Kapital Boost is a crowdfunding platform that allows its members to invest or contribute in an ethical way based on sharia principles. Kapital Boost offers alternative short-term financing for companies/SMEs (Small and Medium Enterprises) with a non-burdensome approval process. Kapital Boost gives its members the opportunity to invest and obtain attractive returns through providing temporary finance to SMEs. The investment has a fast turnover, which is between 90 to 360 days. 
Kapital Boost's crowdfunding platform mechanism is shown in the following picture:

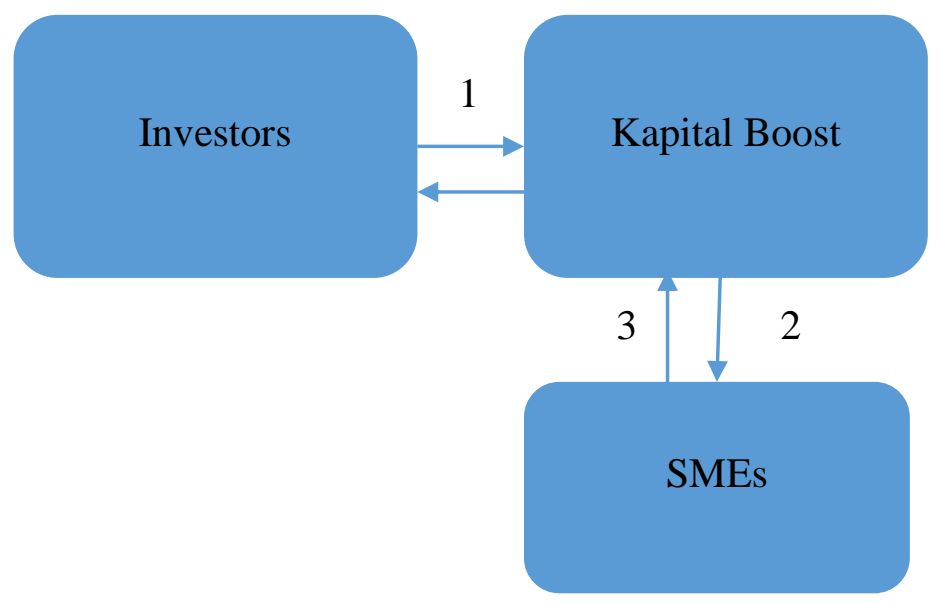

Prospective investors can look for funding campaigns for SMEs in various sectors not only in Indonesia, but also in Malaysia and Singapore. Previously, potential investors would register by filling in their full name and e-mail address. After registering, potential investors can see the details of the funding campaign including company name, funding target, return rate expectations, tenure (time period), and risk profile. After potential investors identify their target campaign and analyze the risk profile and rate of return, investors can invest a minimum of Rp. 2 million. Investors must be very careful before investing their funds as risk analysis is entirely in the hands of the investor. Investors can also ask Kapital Boost via email before deciding to invest. If the investor has agreed to invest funds in a SME, the investor will sign an electronic contract which contains details of the rights and obligations of each party and transfer the agreed amount of funds.

After the fund target is collected, Kapital Boost will transfer funds from the investors to the SMEs. The SME will manage the funds according to the signed contract (purchase of assets or factoring). During the maturity period, the SME returns the investor's funds along with the profit sharing/margin determined during the funding campaign to Kapital Boost. Kapital Boost repays the principal investment plus margin/profit sharing to investors. Kapital Boost also sends the latest funding campaign information to each investor's email.

Fundraising schemes on the Kapital Boost platform can be described through the following picture:

$$
\begin{gathered}
\text { Kapitalboost looks for SMEs } \\
\text { that need funding and in } \\
\text { accordance with the specified } \\
\text { requirements }
\end{gathered}
$$

Kapitalboost displays profiles of SMEs on the website to be chosen by investors
At maturity, SMEs repay the principal investment value and profit sharing to investors through Kapitalboost
SMEs will receive funds from investors to purchase assets / pay off customer orders 
Kapital Boost seeks feasible or feasible SMEs to receive financing. Kapital Boost determines the amount of funding based on invoices deposited by the SMEs. The funding target is determined as $80 \%$ of the invoices/orders paid by the SMEs. The proportion (nisbah) of funding sharing is determined based on an agreement between Kapital Boost and the SMEs. The funding period is determined by the SMEs. Kapital Boost analyzes the risk profile of the SMEs and determines whether or not the SMEs are eligible for funding. After deciding that the SME complies with the conditions specified, Kapital Boost will release a funding campaign on the website to attract investors. The campaign contains all information related to the start up in the form of a company profile, risk assessment, a contract that will be used to fund the startup, profit sharing and the amount of funds that Kapital Boost will collect for the project.

Kapital Boost was established in July 2015 and targets SMEs in the Southeast Asia region, namely Singapore, Malaysia and Indonesia. Although it began in Singapore, Kapital Boost has developed and helped many MSMEs in Indonesia. Among the 3 countries involved in crowdfunding activities, $70 \%$ were distributed to SMEs in Indonesia (Results of the In-depth Interview with the CEO of Kapital Boost).

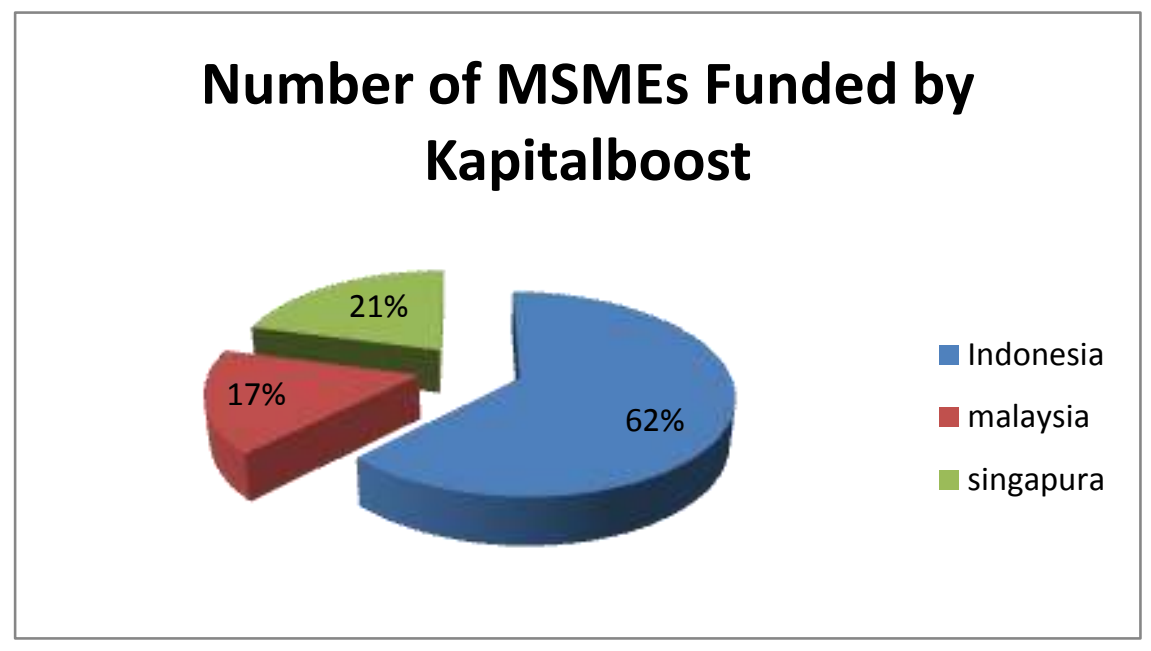

Based on the above picture, it can be seen that the majority of MSMEs funded by Kapital Boost are in Indonesia (62\%). The types of businesses that are funded by MSMEs vary widely from food and beverage, clothing, textiles, shipping, advertising, publishing, machineries and engineering. Singapore is the second highest recipient of funding from Kapital Boost (21\%) including food and beverage, confection, livestock,

\section{Expected Return provided by SMEs}

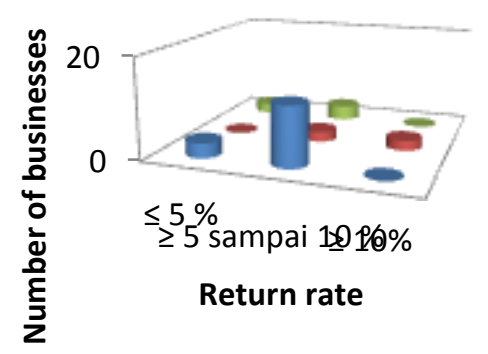

- Indonesia

- Malay

Singapore 
and e-commerce businesses. The least amount of funding is provided to Malaysian business in the food manufacturing, reflexology, ICT, and medical equipment industries.

The difference in the number of businesses funded also affects the amount of capital channeled to the MSMEs of each country. The data shows that there is an alignment of the number of MSMEs funded with capital turnover that has been channeled by Kapital Boost. Of the total funds disbursed, the capital turnover collected in Indonesia is $63 \%$ or as much as SGD 1,347,435. This is followed by $22 \%$ of turnover distributed in Singapore or around SGD 461,300. Lastly, 16\% are in Malaysia with funds amounting to SGD 341,300. From the funds lent to each country, Kapital Boost provides a different range of estimated returns as an illustration for investors. Based on the data obtained from Kapital Boost.com, the number of benefits offered by MSMEs to investors differs in each country.

Then, based on the loans and the expected return offered by the MSMEs, each UMKM will have a different payback period. Further, the duration of the UMKM's ability to provide loans will vary. From the graph below, it is seen that MSMEs in Indonesia funded by crowdfunding by Kapital Boost are typically MSMEs with a 1) medium, 2) high, and 3) low risk. While in Singapore's MSMEs, the risk tends to be primarily low, with a small number of businesses that are medium and high risk. In Malaysia, the risk of the businesses tends to be 1) medium and 2) low. The risk assessment criteria are based on a credit scoring system developed by Kapital Boost. The SME risk profile does not indicate a possible loss or default on the investment portfolio owned by investors.

In the last 3 years, Kapital Boost has provided funding to 35 SMEs from Malaysia, Singapore and Indonesia, with the highest amount of funding per campaign of Rp. 1.5 Billion (for asset purchases). Kapital Boost has therefore collected funding of more than Rp. 44 billion. The majority of SMEs that receive funding are from Indonesia.

When viewed from the funding scheme offered, SMEs propose more funds with an asset purchase scheme than factoring. The following diagram illustrates the proportion of funding campaigns that use factoring schemes with asset purchases:
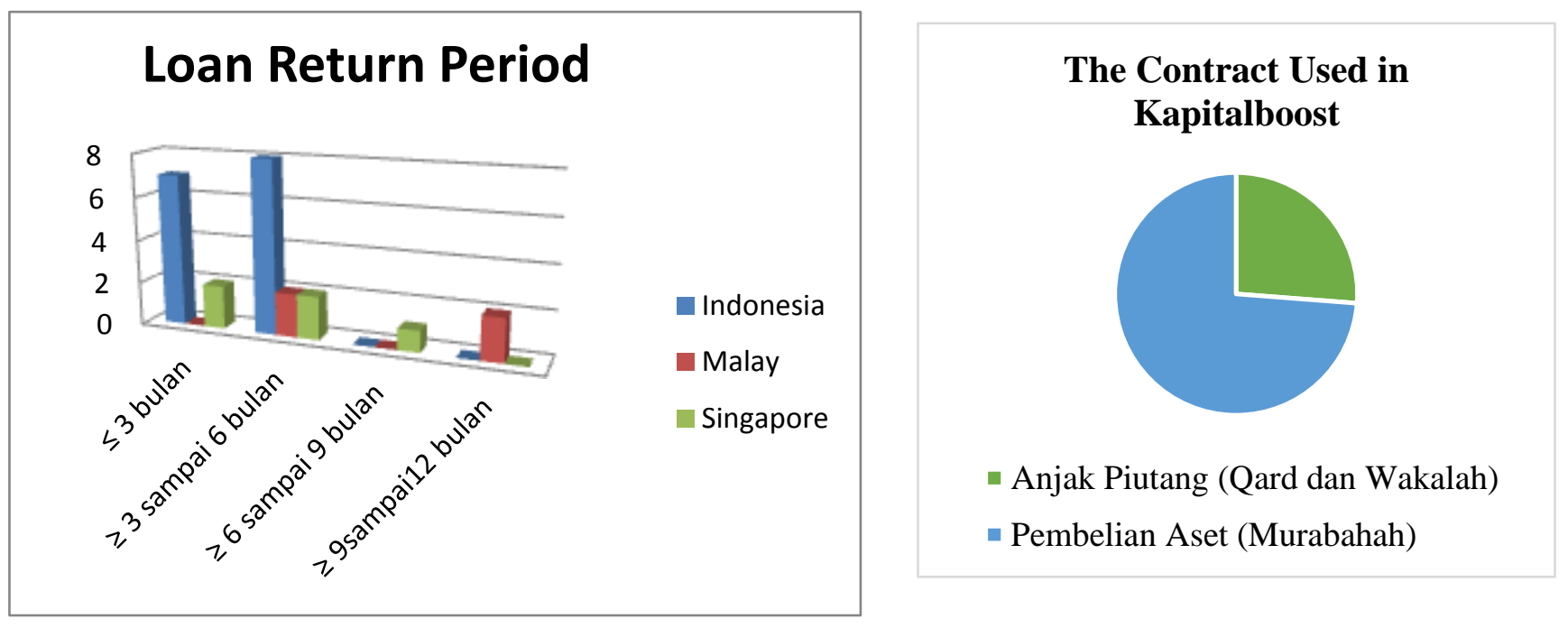

The graph shows that $74 \%$ of SME funding campaigns use the murabahah contract while $26 \%$ use the Qard and Wakalah contract scheme. When viewed from the investor perspective, the murabahah agreement scheme carries less risk than the Qard and Wakalah contract scheme. In the murabahah agreement scheme, investors agree to buy assets which they will sell to SMEs for the cost of the goods plus a profit margin. This scheme requires certainty regarding the purchase price of assets, margins, selling price, and repayment periods to minimize investment risk. 
Kapital Boost not only focuses on funding campaigns that are profit-oriented, but also in funding campaigns that are social or non-profit oriented, hence, Kapital Boost is described as a loan-based crowdfunding company as well as donation-based crowdfunding company. Investors who are registered with Kapital Boost do not provide capital directly or become shareholders in the funded company. Therefore, Kapital Boost is not an equity-crowdfunding company.

\subsection{The Role of Islamic Crowdfunding in the Continuity of MSME's and Start-Up Businesses}

It is easier for a start-up business to obtain funding through crowdfunding than through traditional banking mechanisms (Berger \& Udell, 1998; Berger \& Black, 2011). Crowdfunding connects investors and SMEs. Crowdfunding companies run funding campaigns that aim to raise a relatively small amount of funds for individual projects or activities (Mollick \& Kuppuswamy, 2016).

Kapital Boost monitors the SMEs business developments to ensure that they do not expand too rapidly and misuse their funding. The concept of Business Development refers to the ability to create long-term value of a business including value to customers, markets, and networks. Business Development is characterized by increased profitability and expansion. Activities in business development cover all functional areas namely sales, marketing, product or project management, network building capabilities and partnerships (Forsman, 2008; Pollack, 2015; Bryder, et. al., 2016).

The impact of crowdfunding on business development can be determined by reference to the type of contract applied. In general, the main activity of crowdfunding companies is to raise funds from investors and use that capital to fund the projects of SMEs. Kapital Boost as a crowdfunding company provides two types of SME funding, namely: factoring and asset purchases. Asset purchase schemes can be described through the following picture:

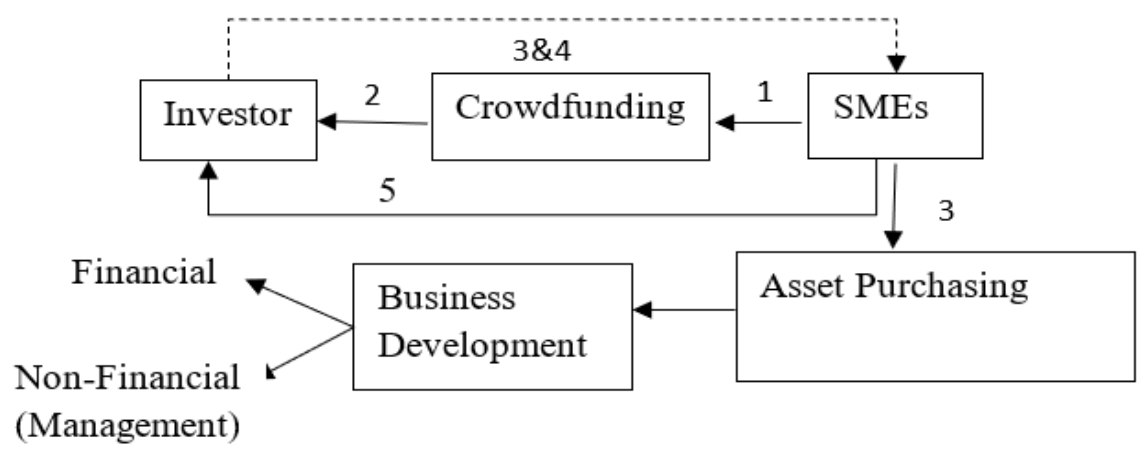

Picture 4.1. Asset Purchase Schemes

SMEs that need financing to buy assets (raw materials, equipment) in order to fulfill customer orders may apply to crowdfunding companies. Crowdfunding companies then analyze the business feasibility of those SMEs. Once it has decided that the particular SMEs deserves funding, the crowdfunding company will release a funding campaign on their platform. Investors agree to raise funds and purchase assets, which then appoints the SMEs as intermediaries / agents to buy assets on behalf of the investors. When the purchase is complete, the investor sells the assets to the SME at cost price plus a profit margin with a strong payment. Then, with assets in hand, the SMEs are able to fulfill their customer orders. 
Through this scheme, SMEs obtain new assets that they then use to expand their business and expand their market share. The factoring schemes are described below.

Picture 4.2. Factoring Schemes

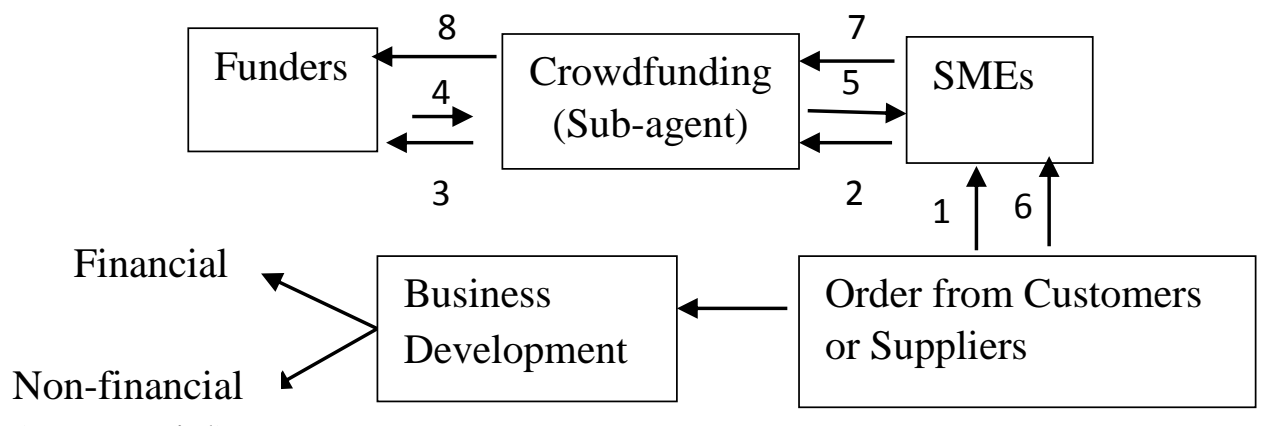

(Managerial)

1. SMEs have completed certain jobs or fulfilled customer's orders but customers have not completed payment (Customers are still indebted to SMEs). SMEs then issue invoices to customers for goods that have been sold and completed work with a payment period of 30-90 days.

2. While waiting for customers to settle payments, SMEs seek loans from cash funds using a Qord contract of $85 \%$ of the invoice value to crowdfunding companies.

3. Crowdfunding companies analyze funding proposals from SMEs. After SMEs are declared eligible for funding, crowdfunding companies release funding campaigns to Funders.

4. Funders appoint crowdfunding companies as sub-agents to carry out accounts receivable management services.

5. Crowdfunding investor hands over loans without interest to the SMEs.

6. At the invoice deadline, the Customer will pay to the SME in accordance with the amount stated on the invoice.

7. SMEs pay loan principal and agency fees to crowdfunding companies.

8. Crowdfunding companies pay loan principal and agency fees to Funders.

\subsection{Business Development}

When viewed from a financial perspective, factoring schemes provide a number of positive impacts on the development of SMEs. Cash flows from the SME are more liquid and the liquidity ratio of SMEs is also improved. SMEs obtain cash faster to meet their working capital and ensure business operations run well.

Business development of startup companies that get crowdfunding funding can be divided into two categories, namely: financial aspects and non-financial aspects (managerial).

SMEs that obtain funding through crowdfunding platforms have better financial performance than before they received the funding. The performance of SMEs in terms of liquidity is also improved and company assets are increased (if using an asset purchase scheme). This is demonstrated by the development of the total funding of two start-up businesses that have the highest launching campaign frequency in Kapital Boost. 


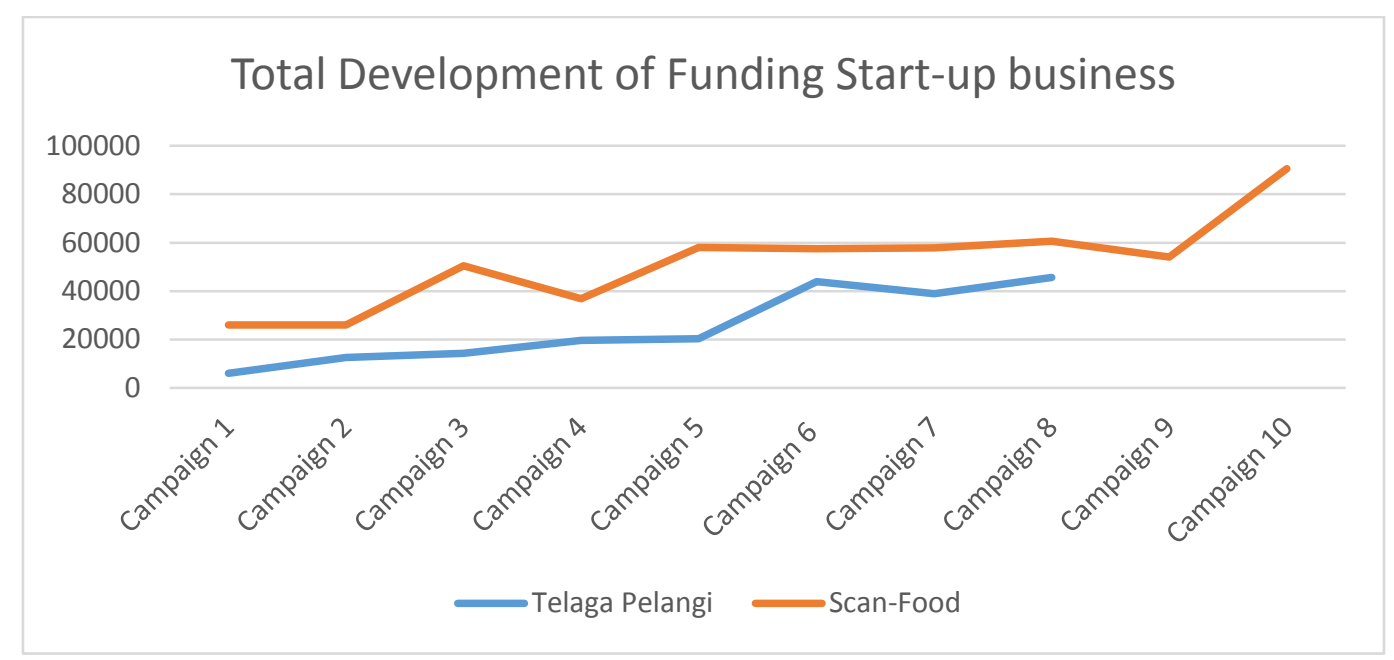

PT Telaga Pelangi and Scan-Food, Ltd released the most funding campaigns on the Kapital Boost platform in 2018. It can be seen from the graph that the amount of funding obtained from their first campaign to their latest campaign has continued to increase. This increase reflects the improvement of their performance each time they receive funding. Kapital Boost only distributes funding to companies that have positive cash flow and have good business prospects. Sustainable business drives long term growth and profitability, mandating inclusion of environmental and social issues in business models.

1. Increased resilience and adaptation to change.

2. Increase innovation and faster development of new products and services.

3. Reduces cost of energy, waste and materials.

4. Improves morale and productivity of employees.

5. Improves reputation and recognition from customers, suppliers and peers.

6. Lowers business risk and improves safety.

In terms of the non-financial aspects, SMEs that obtain funding through crowdfunding are more transparent and accountable in their financial reporting. This is due to the obligation to periodically disclose business financial reports to crowdfunding companies and investors. In addition, with the crowdfunding mechanism, SMEs can recruit more employees and increase the scale of their business more than before receiving the funding.

\section{Conclusion}

Based on the results of this study and the discussion above, it can be concluded that the role of Islamic crowdfunding contributes positively to the business development of <SMEs, including increased sales, increased market share and easier provision of additional capital with profit sharing principles (according to sharia law). The efforts made by Kapital Boost help to achieve financial success for MSMEs in all functional areas including sales, marketing, product management, networks and partnerships.

Regulators must formulate regulations and laws that govern crowdfunding companies in order to allow them to operate in each state. Sharia-based crowdfunding companies need to inform the public periodically through their website on the development of MSME businesses that have received funding, through financial statements and annual reports, to enable investors and researchers to analyze and evaluate the performance of crowdfunding to MSMEs. Subsequent research should examine existing regulations and propose new regulations in the area of crowdfunding. 


\section{References}

Abdullah, Apnizan. Crowd Funding as an Emerging Fundraising Tool: With Special Reference to The Malaysian Regulatory Framework. Journal of Islam and Civilizational Renewal, pp. 98-11.

Ahammed, Mushthaq. (2017). Sharia Compliant Crowd Funding: An Alternative Optimal Platform For Funding MSMES. Kaav International Journal of Economics, Commerce and Business Management, 4(3), pp. 87-93

Andaleeb, Aruba and A. K Mishra. (2016). Equity Crowdfunding in Shariah Compliant Nation: An Outlook in the Middle East. Global Journal of Finance and Management. 8(1), pp. 97-102

Asutay, M and Marzban, Shehab. (2012) Standing Out With Crowd. The Banker Special Report: Top Islamic Financial Institutions. Financial Times Publication, pp. 28-29.

Belleflamme, Paul, et. al., (2013). Crowdfunding: Tapping the Right Crowd. Journal of Business Venturing.

Belleflamme, Paul. (2015). The Economics of Crowdfunding Platforms. Information Economics and Policy.

Bento, Nuno, et. al., (2018), Do Crowdfunding Returns Reward Risk? Evidences From Clean-tech Projects. Technological Forecasting and Social Change.

Berger, A. N. and Black, L. K. (2011). Bank Size, Lending Technologies and Small Business Finance. Journal of Banking and Finance, 35(3), pp. 724-735.

Berger, A. N. and Udell, G. F. (1998). The Economics of Small Business Finance: The Roles of Private Equity and Debt Markets in the Financial Growth Cycle. Journal of Banking and Finance, 22(6), pp. 613-673.

Berliner, L. S., Kenworthy, N. Worthy Illness: Personal Crowdfunding Amidst Financial Crisis, Social Science and Medicine.

Bitterl, Sally and Martin Schreier. (2018). When Consumers Become Project Backers: The Psychological Consequences of Participation in Crowdfunding. International Journal of Research in Marketing.

Brem, Alexander, Volker Bilgramc, Anna Marchukc. (2017). How Crowdfunding Platforms Change the Nature of User Innovation - From Problem Solving to Entrepreneurship. Technological Forecasting and Social Change.

Bretschneider, Ulrich and Jan Marco Leimeister. (2017). Not Just an Ego-trip: Exploring Backers' Motivation for Funding in Incentive-based Crowdfunding. Journal of Strategic Information Systems.

Brown, Ross, et. al., (2018). Start-ups, Entrepreneurial Networks and Equity Crowdfunding: A Process Perspective. Industrial Marketing Management.

Chen, Jun, et. al. (2018). Mechanism and Policy Combination of Technical Sustainable Entrepreneurship Crowdfunding in China: A System Dynamics Analysis, Journal of Cleaner Production.

Cosh, Douglas J. Cumming and Alan Hughes, (2009) “Outside Entrepreneurial Capital”, Economic Journal, 119.

Colombo, M. G., Franzoni, C. and Rossi-Lamastra, C. (2015). Internal Social Capital and the Attraction of Early Contributions in Crowdfunding. Entrepreneurship Theory and Practice, 39(1), pp. 75-100.

Financial Conduct Authority (2015). A Review of the Regulatory Regime for Crowdfunding and the Promotion of Nonreadily Realizable Securities by Other Media. London, UK: FCA.

Forsman, Helena. (2008). Business Development Success in SMEs: A Case Study Approach. Journal of Small Business and Enterprise Development, 15(3), pp. 606-622,

Global Entrepreneur Monitor. (2013). Global Report. Global Entrepreneurship Research Association.

Hellman, Jens Laage, Mari Landqvist, Frida Lind. (2018). Business Creation in Networks: How a Technology-based Start-up Collaborates with Customers in Product Development. Journal Industrial Marketing Management.

Indonesia Startup Report (2015).

Kapital Boost.com

Joakim Winborg \& Hans Landstrom, "Financial Bootstrapping in Small Businesses: Examining Small Business Managers'Resource Acquisition Behaviours", Journal of Business Venturing, Vol. 16 (2001):

Marzban, Shehab and Mehment Asutay. (2014). .Shariah-Compliant Crowdfunding: An Efficient Framewrok for Entreprenurship Development in Islamic Countries. Harvard Islamic Finance Forum

McEwen, T. (2013). An examination of the barriers that impact the implementation of environmental sustainability practices in small businesses. Journal of Business and Entrepreneurship, 25(1), 117-139

Moleong, lexy J. (2009). Metode penelitian kualitatif. Bandung: PT. Remaja Rosdakarya

Mollick, E. (2014). The dynamics of crowdfunding: An Exploratory Study. Journal of Business Venturng.Vol. 4 pp. 231-248. 
Najah, Ahlem and Anis Jarboui. (2015). Crowdfunding for Financing Innovative and Social Entrepreneurship: Literature Review. Journal of Business Management and Economics.3.p 21-25

Pais, I., \& Castrataro, D. (2014). Crowdfunding and free labor: gift, exploitation or investment?.Sociologia del lavoro. Pollack, John. What, Exactly, Is Business Development?". Forbes. Retrieved 2015-11-0

Rees-Mogg, M. (2013).Crowd funding: How to raise money and make money in the crowd. Crimson.

Sugiyono, prof. Dr. (2012). Metode penelitian kuantitatif, kualitatif, dan R\&D. Bandung: Alfabeta

Wahjono, S. I., \& Marina, A. Islamic Crowdfunding : Alternative Funding Solution

World Economic Forum and Booz \&Company 2011

Yin, Robert K. (2009). Studi kasus : desain \& metode. Jakarta : Rajawali pers

Ahhamed, Mushthaq. Sharia Compliant Crowdfunding: An Alternative Optimal Platform For Funding MSEMs.

(2017). Journal Of Economics, Commerce \& Business Management. Vol.4.87-93 